\title{
Financial Performance of RGT \& PE Concepts Pvt. Ltd Chennai
}

\author{
Gowtham Aasirvad, A.Ravikumar, R.Ramamoorthy
}

\begin{abstract}
Ltd intends to discover the productivity of the association utilizing budgetary proportions, turnover proportion and dissolvability proportion of the association and to discover the liquidity position of the association, to think about execution of association through relative examination and give appropriate propose improving the monetary exhibition of the association.
\end{abstract}

The task is related to the organization's information accessible for as far back as five years. The ends are drawn from the investigation done by the proportions, relative, regular size examination. The investigation clarifies the monetary position of the association regarding the previous five years. It causes the association to put itself among different other aggressive organizations. [1],[3],[5]

The investigation through the examination uncovers the upsides and downsides of the association budgetary status. It empowers the peruser to comprehend the different money related parts of an organization through uncomplicated translation and finding for study reason. [2 ],[ 4],[6]

Keywords : performance analysis,ratio

\section{INTRODUCTION}

Assessment of Financial execution is the route toward perceiving the budgetary characteristics and deficiencies of the firm by fittingly setting up the association between the things of advantage report and advantage and mishap account. It moreover helps in present minute and whole deal envisioning and advancement can be identified with the help of cash related execution examination. The dictionary noteworthiness of 'examination' is to decide or separate a thing in to its segment or portions parts for following their association with the things as whole and to each other. The examination of spending report is a technique of evaluating the association between the fragment bits of monetary report to get a predominant understanding of the unbendable position's and performace. This assessment can be grasped by the administrators of the firm or by social affairs outside the specifically, owners, advance managers, money related authorities. segment some portion of budget report to get a superior comprehension of the inflexible stance's and

Revised Manuscript Received on July 22, 2019.

Gowtham Aasirvad, Department of MBA, Bharath Institute of Higher Education and Research,Tamilnadu,India.Email: kgowthamaashirwad123@gmail.com

Dr.A.Ravikumar, Department of THM, Bharath Institute of Higher Education and Research, Tamilnadu, India. Email: ravikumar.th@bharathuniv.ac.in

R.Ramamoorthy, Department of THM, Bharath Institute of Higher Education and Research, Tamilnadu, India. Email: ramamoorthy0071@gmail.com execution. This examination can be attempted by the board of the or by gatherings outside the to be specific, proprietors, speculators and others.

\section{A. MEANING OF FINANCIAL STATEMENT}

A spending report is a get-together of data dealt with agreeing and unfaltering accounting methods. Its inspiration is to pass on a cognizance of some cash related pieces of a business firm. It may exhibit a circumstance at a moment in times as because of a financial record, or it may reveal course of action of activities over a given time of times, as by virtue of a compensation clarification. [7],[ 9] ,[11]

The declaration revealing status of endeavors is known as money related record and the declaration exhibiting the result is known as advantage and incident record". Thusly, the term spending report has been comprehensively used to address two clarification organized by clerks close to the completion of unequivocal period. They are: (1) advantage and incident record or pay explanation; and (2) Balance sheet or declaration of budgetary position. [8],[ 10] ,[12]

Monetary reports are set up as a last result of cash related accounting and are those which can be conveyed in money related terms. The declarations are also called as cash related reports. [13], [15], [17]

\section{DATA ANALYSIS AND INTERPRETATION}

\section{RATIO ANALYSIS}

Table 1 CURRENT RATIO

\begin{tabular}{|l|l|l|l|}
\hline YEAR & CURRENT ASSETS & $\begin{array}{l}\text { CURRENT } \\
\text { LIABILITIES }\end{array}$ & RATIO \\
\hline 2016 & $76,27,301$ & $66,89,865$ & 1.14 \\
\hline 2015 & $25,17,082$ & $73,91,018$ & 0.34 \\
\hline 2014 & $75,15,766$ & $1,32,43,899$ & 0.57 \\
\hline 2013 & $73,23,478$ & $1,10,06,206$ & 0.67 \\
\hline 2012 & $4,14,177$ & $7,34,505$ & 0.56 \\
\hline
\end{tabular}


Financial Performance of RGT \& PE Concepts Pvt. Ltd Chennai

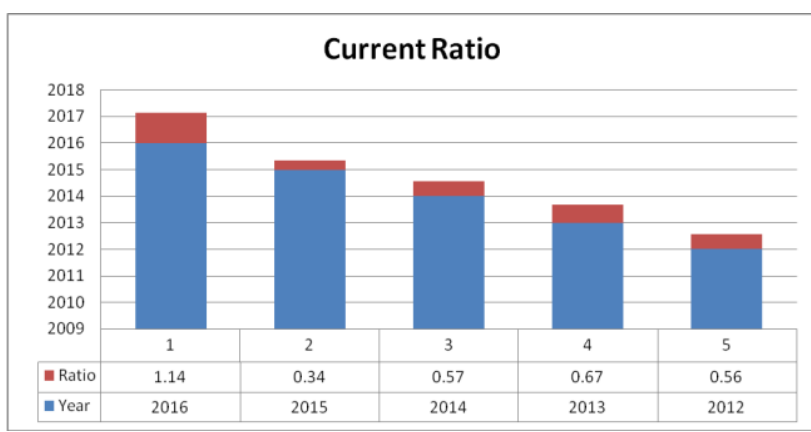

Fig:1 Current Ratio

Table 2 QUICK RATIO

\begin{tabular}{|l|l|l|l|}
\hline YEAR & $\begin{array}{l}\text { TOTAL } \\
\text { INVENTORY }\end{array}$ & $\begin{array}{l}\text { CURRENT } \\
\text { LIABILITIES }\end{array}$ & RATIO \\
\hline 2016 & $66,40,697$ & $66,89,865$ & 0.99 \\
\hline 2015 & $13,19,316$ & $73,91,018$ & 0.18 \\
\hline 2014 & $68,84,553$ & $1,32,43,899$ & 0.52 \\
\hline 2013 & $68,84,553$ & $1,10,06,206$ & 0.63 \\
\hline 2012 & $4,14,177$ & $7,34,505$ & 0.56 \\
\hline
\end{tabular}

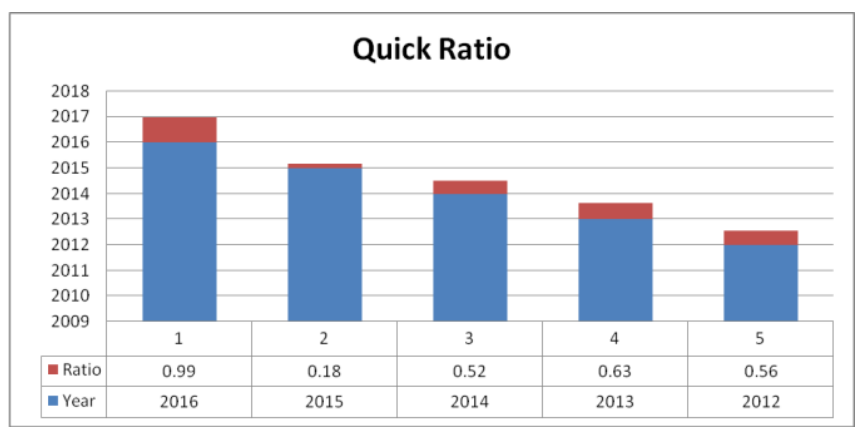

Fig:2 Quick Ratio

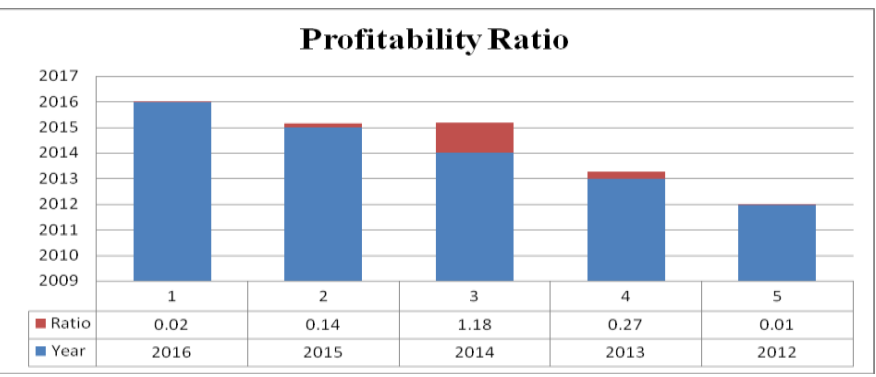

Fig:3 Profitability ratio

Table:4 GROSS PROFIT RATIO

\begin{tabular}{|l|l|l|l|}
\hline YEAR & GROSS PROFIT & NET SALES & RATIO \\
\hline 2016 & $1,85,181$ & $95,57,130$ & 1.94 \\
\hline 2015 & $6,15,755$ & $1,58,86,150$ & 3.88 \\
\hline 2014 & $16,52,897$ & $1,06,33,583$ & 15.54 \\
\hline 2013 & $24,50,813$ & $88,73,823$ & 27.62 \\
\hline 2012 & 16,994 & $37,11,455$ & 0.46 \\
\hline
\end{tabular}

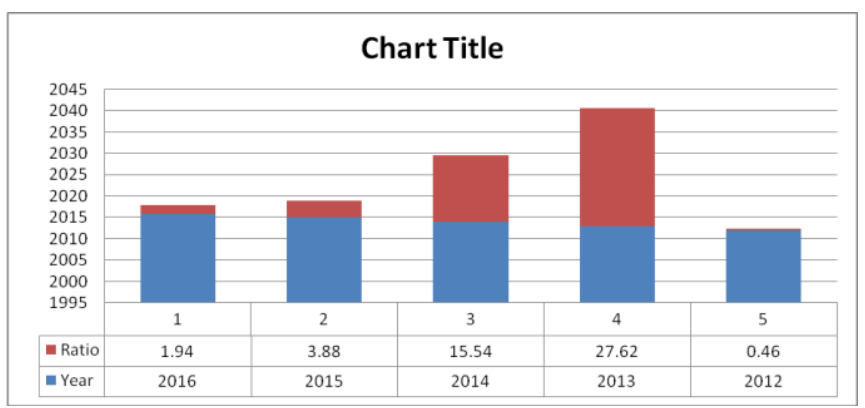

Fig:4 Gross profit ratio

Table:5 WORKING CAPITAL TURNOVER RATIO

\begin{tabular}{|l|l|l|l|}
\hline YEAR & REVENUE & $\begin{array}{l}\text { WORKING } \\
\text { CAPITAL }\end{array}$ & RATIO \\
\hline 2016 & $96,71,312$ & $9,37,436$ & 10.32 \\
\hline 2015 & $1,63,61,419$ & $48,73,936$ & 3.36 \\
\hline 2014 & $91,10,475$ & $57,28,133$ & 1.59 \\
\hline 2013 & $56,78,935$ & $36,82,728$ & 1.54 \\
\hline 2012 & $36,84,690$ & $3,20,328$ & 11.50 \\
\hline
\end{tabular}

\begin{tabular}{|l|l|l|l|}
\hline YEAR & NET PROFIT & TOTAL ASSETS & RATIO \\
\hline 2016 & & & \\
\hline 2015 & $1,85,181$ & $92,57,105$ & 0.02 \\
\hline 2014 & $6,15,755$ & $44,88,426$ & 0.14 \\
\hline 2013 & $16,52,897$ & $99,14,000$ & 1.18 \\
\hline 2012 & $24,50,813$ & $92,31,550$ & 0.27 \\
\hline
\end{tabular}




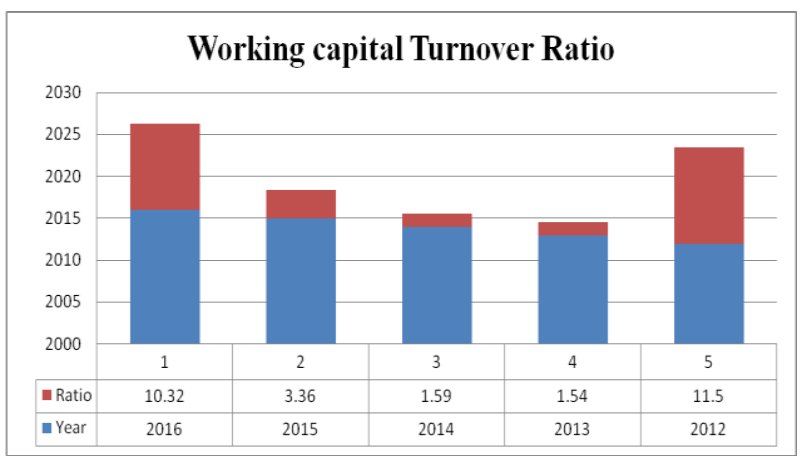

Fig:5 WORKING CAPITAL TURNOVER RATIO

Table:2 Comparative Balance Sheet (2015-2016) (Rs In Crs)

\begin{tabular}{|c|c|c|c|c|}
\hline & A & B & $C=A-B$ & $\mathrm{D}=\mathrm{C} / \mathrm{A}^{*} 100$ \\
\hline I.EOUITY & & & & \\
\hline \multicolumn{5}{|l|}{ (1)Shareholder's Fund } \\
\hline a. Share capital & 1.00 .000 & 1.00 .000 & 0 & 0 \\
\hline b. Reserves and surplus & 35.45 .717 & 33.60 .536 & 1.85 .181 & 5.22 \\
\hline c. Money reserved against & . & $\begin{array}{ll}- \\
\end{array}$ & $-\quad$ &. \\
\hline \multicolumn{5}{|l|}{ (2)Non-current liabilities: } \\
\hline a. Long-term borrowings & 5.43 .125 & 3.24 .177 & 2.18 .948 & 40.31 \\
\hline b. Deferred tax liabilities & & - & - & - \\
\hline c. Other long-tem & 18.19 .443 & 55.03 .598 & 36.84 .155 & 202.48 \\
\hline d. Long-term provisions & - & - & - & - \\
\hline \multicolumn{5}{|l|}{ (3)current liabilities: } \\
\hline a. Trade pavables & 35.55 .627 & 59.06 .234 & 23.50 .607 & 66.11 \\
\hline b. Other current liabilities & 16.93 .420 & 4.48 .270 & 12.45 .150 & 73.53 \\
\hline c. Short-tem provisions & 3.22 .529 & 3.35 .361 & 12.832 & 3.98 \\
\hline d. Short-tem borrowings & & & & \\
\hline TOTAL & 11.579 .861 & 15.978 .176 & 43.98 .315 & 37.98 \\
\hline \multicolumn{5}{|l|}{ II.ASSETS } \\
\hline \multicolumn{5}{|l|}{ (1)Non-current assets } \\
\hline a. Fixed Assets & 14.41 .260 & 10.13 .721 & 427539 & 29.66 \\
\hline b. Non-current investments & & & & \\
\hline c. Deferred tax assets & 1.70 .084 & 2.41 .083 & 70.999 & 41.74 \\
\hline d. Long-term loans and & 3.60 .000 & 3.75 .000 & 15.000 & 4.16 \\
\hline \multicolumn{5}{|l|}{ (2)Current assets } \\
\hline a. Inventories & 13.19 .316 & 66.40 .697 & 53.21 .381 & 403.34 \\
\hline b. Trade receivable & 4.83 .174 & 6.63 .995 & 1.80 .821 & 37.42 \\
\hline c. Cash and cash & 4.04 .822 & 36.864 & 3.67 .958 & 90.89 \\
\hline d. Short-tem loans and & 1.20 .500 & 87.000 & 33.500 & 27.80 \\
\hline e. Other current assets & 1.89 .269 & 1.98 .745 & 9.476 & 5.00 \\
\hline TOTAL & 44.89 .425 & $92.57,105$ & $47,68.680$ & 106.24 \\
\hline
\end{tabular}

\section{INFERENCE}

From the above table, it is construed that the other long haul liabilities expanded up to $202.48 \%$, and other current liabilities expanded up to $73.53 \%$, and exchange payables expanded up to $66.11 \%$, and long haul borrowings expanded up to $40.31 \%$, and hold and surplus expanded up to $5.22 \%$, and momentary arrangements expanded up to $3.98 \%$, and inventories expanded up to $403.34 \%$, and money and money reciprocals expanded up to $90.89 \%$, and conceded charge resources (NET) expanded up to $41.72 \%$, and Trade receivable expanded up to $37.42 \%$, and Fixed Assets expanded up to $29.66 \%$, and Short-term advances and advances expanded up to $27.80 \%$, and Other current resources expanded up to $5.00 \%$, and Long-term credits and advances expanded up to $4.16 \%$, in the present year (2016) when contrasted and earlier year (2011) [14],[ 16], [18]

\section{III.RESULTS}

- The current proportion has expanded as 1.14 during the year 2016.

- The fluid proportion has expanded as 0.99 during the year 2016.

- The productivity proportion has expanded has 1.18 during the year 2014.

- The gross benefit proportion has expanded has 27.62 during the year 2013.

- The working capital turnover proportion has expanded has 10.32 during the year 2016 .

- The similar accounting report that other long haul liabilities expanded up to $202.48 \%$ and other current liabilities expanded up to $73.53 \%$, in the present year (2016) when contrasted and earlier year (2015).

- The relative asset report that other current liabilities expanded up to $64.55 \%$ and exchange payable expanded up to $56.32 \%$, in the present year (2015) when contrasted and earlier year (2014). [25],[27],[29]

- The near accounting report that Reserves and surplus expanded up to $165.89 \%$, and other current liabilities up to $48.69 \%$, in the present year (2014) when contrasted and earlier year (2013).

- The near asset report that Reserves and surplus expanded up to $4242.80 \%$ and exchange payables expanded up to $1747.10 \%$, in the present year (2013) when contrasted and earlier year (2012).

- The normal size asset report that offer capital diminished from $0.86 \%$ (2015) up to $0.63 \%$ (2016). [20],[22], [24]

- The regular size monetary record that Share capital expanded from $0.55 \%$ (2014).

- The regular size monetary record that Share capital 0.70\%(2013) diminished 0.55\% (2014).

- The regular size monetary record that Share capital $6.55 \%$ (2012) diminished $0.70 \%$ (2013).

\section{IV.DISCUSSION}

- Company may investigate the measures how to decrease the and propels in the coming time frames. [19],[21],[23]

- Company may investigate keep up the present resources and current liabilities, current liabilities may diminish coming periods. 
- It is recommended to the organization can emphatically concentrate on cost decrease procedure that will make an organization greater benefit.

- The organization has a brilliant future on the off chance that it focuses more on its working capital present moment, speculations, along these lines accomplishing the general targets of the organization.

- Thus it is basic to stay away from over the top liquidity however to keep up adequate liquidity to guarantee smooth running of the organization's activity.

- The organization has better liquidity position and needs to keep up same later on.

\section{CONCLUSION}

The effective and smooth working of the considerable number of exercises of the organization relies on the monetary presentation of the organization. The budgetary presentation examination therefore is a forward looking activity as it is useful in future money related arranging basic leadership. It decide to investigation anticipating future money related position. In spite of the fact that fiscal report examination, the present position and working proficiency of the firm overall and its distinctive departmenta can be recognized. Further, the explanations behind change in the productivity monetary position of the firm can be found and fundamental measures can be taken. [26],[28],[30]

Money related execution can improve the monetary quality of organization. The organization's liquidity position needs to increment and it will take care of future issue. The organization is keeping up the stores and surplus better so it can confront money related worry later on. To appropriate keep up of money related execution to accomplish the organization objective[31],[33],[32]

\section{REFERENCES}

1. G BharthVajan R., Ramachandran S.,Psychographic dimensions of training,2016,International Journal of Pharmacy and Technology,V-8,I-4,P-23727-23729

2. Balakrishnan P., Bharthvajan R.,A study on human resource planning in hospitals in Chennai City,2014,International Journal of Applied Engineering Research,V-9,I-22,P-7503-7507

3. Priyadarsini P., Bharthvajan R.,Role of emotional intelligence training programme in reducing the stress of the nurses,2014,International Journal of Applied Engineering Research,V-9,I-22,P-7411-7421

4. Kerinab Beenu G., Bharthvajan R.,Empirical analysis on the cosmetic buying behavior of young women in South India,2014,International Journal of Applied Engineering Research,V-9,I-22,P-7361-7366

5. Balakrishnan P., Bharthvajan R.,Whistling in the wind,2014,International Journal of Applied Engineering Research,V-9,I-22,P-7586-7593

6. Krishnan B., Peter M.,Health hazards of Indian Bpo employee-an alarming issue,2014,International Journal of Applied Engineering Research,V-9,I-22,P-7336-7341

7. Kerinab Beenu G.H., Peter M.,Role of insurance in economic development,2014,International Journal of Applied Engineering Research,V-9,I-22,P-7532-7539

8. Balakrishnan P., Peter M., Priyadarsini P.,Efficiency of safety measures for wellbeing of employees in manufacturing industry,2014,International Journal of Applied Engineering Research,V-9,I-22,P-7376-7382

9. Anbarasi M., Praveen Kumar S.,Online sales promotions of herbal products and its effectiveness towards tanisha.com,2019,Indian Journal of Public Health Research and Development,V-10,I-1,P-195-200

10. Anbarasi M., Praveen Kumar S.,Various online marketing and promotions strategies to improve the validation towards the organic products in the pharmaceutical sectors,2019,Indian Journal of Public Health Research and Development,V-10,I-1,P-263-269

11. Loganathan R., Praveen Kumar S.,Grievance handling a key factor for solving issues of employees in an organization,2014,International Journal of Applied Engineering Research,V-9,I-22,P-7483-7491

12. Loganathan R., Praveen Kumar S.,Study on preference of private label brands in super and Hypermarkets, 2014,International Journal of Applied Engineering Research,V-9,I-22,P-7327-7335

13. Smitha M., Praveen Kumar S.,Understanding stress and its managementamong the nurses in Chennai city,2014,International Journal of Applied Engineering Research,V-9,I-22,P-7560-7565

14. Kerinab Beenu G.H., Praveen Kumar S.,A study on the investment behavior of Chennai investors in mutual fund schemes,2014,International Journal of Applied Engineering Research,V-9,I-22,P-7520-7525

15. Loganathan R., Praveen Kumar S.,Retention strategies key for organizational productivity,2014,International Journal of Applied Engineering Research,V-9,I-22,P-7443-7447

16. Pavithra J., Ganesan M., Brindha G.,State wise analysis of microfinance sector in India,2016,International Journal of Pharmacy and Technology,V-8,I-4,P-23417-23432

17. Pavithra J., Ganesan M.,A comparative study on microfinance in India and abroad,2016,International Journal of Applied Business and Economic Research,V-14,I-8,P-5471-5476

18. Pavithra J., Ganesan M.,A study on awareness and impact of micro-financial schemes,2016,International Journal of Applied Business and Economic Research,V-14,I-8,P-5449-5460

19. Senthilmurugan P., Pavithra J.,Consumer preference towards organised retailing with reference to Big Bazaar,2014,International Journal of Applied Engineering Research,V-9,I-22,P-7469-7475

20. Senthilmurugan P., Pavithra J.,Implication of social media marketing in growing healthcare industry,2014,International Journal of Applied Engineering Research,V-9,I-22,P-7448-7456

21. Loganathan R., Pavithra J.,Consumer perception towards private label brand over other brands in super markets and hypermarkets,2014,International Journal of Applied Engineering Research,V-9,I-22,P-7355-7360

22. Kerinab Beenu G., Pavithra J.,Tradeâ€"off between liquidity and profitability in logistics industry,2014,International Journal of Applied Engineering Research,V-9,I-22,P-7398-7401

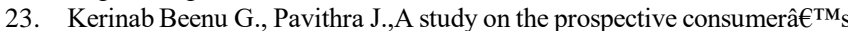
perception towards utility cars in Chennai city,2014,International Journal of Applied Engineering Research,V-9,I-22,P-7526-7531

24. Pavithra J., Dilli Babu P., Ambuli T.V.,A study on budgetary control at Maruti Service Masters, Chennai,2014,International Journal of Applied Business and Economic Research,V-12,I-2,P-151-161

25. Pavithra J., Dilli Babu P., Ambuli T.V.,A study on customer satisfaction of retro Garments Pvt Ltd, Chennai,2014,International Journal of Applied Business and Economic Research,V-12,I-2,P-381-391

26. Kerinab Beenu G.H., Pavithra J., Senthilmurugan P.,A study on the influence of promotional activities for TATA ARIA among consumers in Chennai,2014,International Journal of Applied Engineering Research,V-9,I-22,P-7572-7578

27. Vijayaragavan S.P.,An investigative expert that's general FBG sensors,International Journal of Mechanical Engineering and Technology,V-8,I-8,PP-1500-1505,Y-2017

28. Vijayaragavan S.P.,Equalization routing protocol for Wi-Fi sensor strategy,International Journal of Mechanical Engineering and Technology,V-8,I-8,PP-1662-1666,Y-2017

29. Karthik B., Kiran Kumar T.V.U., Vijayaragavan P., Bharath Kumaran E.,Design of a digital PLL using 0.35 $\hat{\mathrm{I}}^{1 / 4 \mathrm{~m}}$ CMOS technology,Middle East Journal of Scientific Research,V-18,I-12,PP-1803-1806,Y-2013

30. Kanniga E., Selvaramarathnam K., Sundararajan M.,Kandigital bike operating system,Middle - East Journal of Scientific Research,V

31. Jasmin M., Vigneshwaran T., Beulah Hemalatha S.,Design of power aware on chip embedded memory based FSM encoding in FPGA,International Journal of Applied Engineering Research,V-10,I-2,PP-4487-4496,Y-2015

32. Jasmin M.,Optimization techniques for low power VLSI circuits,Middle East Journal of Scientific Research,V-20,I-9,PP-1082-1087,Y-2014

33. Jasmin M., Vigneswaran T.,Fuzzy controller for error control of on - Chip communication,2017 International Conference on Algorithms, Methodology, Models and Applications in Emerging Technologies, ICAMMAET 2017,V-2017-January,I-,PP-1-5,Y-2017 


\section{AUTHORS PROFILE}

Gowtham Aasirvad Assistant Professor ,Department of MBA, Bharath Institute of Higher Education and Research, Tamilnadu, India

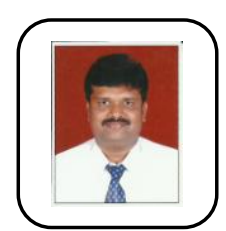

Dr.A.Ravikumar Associate Professor ,Department of THM, Bharath Institute of Higher Education and Research, Tamilnadu, India

R.Ramamoorthy Assistant Professor ,Department of MBA, Bharath Institute of Higher Education and Research, Tamilnadu, India. 